\title{
Stage predictivity of neutrophil/lymphocyte and platelet/lymphocyte ratios in pancreatic neuroendocrine tumors
}

\author{
Kürşat Dikmen ${ }^{1}\left(\right.$ ID), Mustafa Kerem ${ }^{1}($ ID) \\ ${ }^{1}$ Department of General Surgery, Gazi University School of Medicine, Ankara, Turkey
}

\section{ABSTRACT}

Objective: This study aimed to analyze the correlations between European Neuroendocrine Tumor Society (ENEST), Tumor Node Metastasis (TNM) staging systems and pre-operative neutrophil/lymphocyte (NLR) and platelet/lymphocyte ratios (PLR) in patients with pancreatic neuroendocrine tumor (PNET).

Material and Methods: Forty-four patients with diagnosed PNET were analyzed retrospectively. Accordingly, the patients' blood and clinicopathological parameters were analyzed. The correlations between laboratory parameters and tumor stages were evaluated using Eta correlation analysis. The control group was composed of volunteering healthy participants who had similarities with our study group as regards age and gender.

Results: According to ENETS classification, $34 \%$ of the patients were stage I, $25 \%$ were stage II, $20.4 \%$ were stage III and $20.4 \%$ were stage IV. NLR and PLR mean values were 2.4 and 127, respectively. NLR values of the patients in the study group were higher than those of the control group ( $p=0.001$ ). NLR and PLR values of stage I, II, III and IV patients tended to increase in parallel to the higher stages according to ENETS system ( $p=0.0001$ and $p=0.0001$, respectively). Similarly, NLR and PLR values increased in parallel to the higher stages according to TNM system ( $p=0.0001$ and $p=0.0001$, respectively). In addition, NLR values were found to be higher in patients with lymph node metastasis than in those without $(p=0.001)$.

Conclusion: Increased levels of inflammatory mediators such as NLR and PLR are associated with advanced stages of patients with PNET.

Keywords: Pancreas, neuroendocrine tumor, inflammation, stage

Cite this article as: Dikmen K, Kerem M. Stage predictivity of neutrophil/lymphocyte and platelet/lymphocyte ratios in pancreatic neuroendocrine tumors. Turk J Surg 2020; 36 (1): 1-8.

\section{Corresponding Author}

Kürşat Dikmen

E-mail: kursatdikmen@yahoo.com

Received: 22.11.2018

Accepted: 27.05 .2019

Available Online Date: 18.03.2020

o Copyright 2020 by Turkish Surgical Society Available online at www.turkjsurg.com

DOI: $10.5578 /$ turkjsurg.4375

\section{INTRODUCTION}

Pancreatic neuroendocrine tumors (PNET) are rarely encountered but clinically significant tumors. They are seen approximately at the rate of one out of a hundred thousand all over the world and they constitute 1-2\% of malignancy stemming from the pancreas (1-4). Since the majority of PNETs are non-functional tumors, they are usually diagnosed incidentally. Even if they are diagnosed incidentally or at a smaller size, they can display aggressive progression (5). PNETs are heterogeneous neoplasms with biological behaviors at a wide spectrum (6,7). Significant prognostic factors such as mitotic ratio, nuclear grade, vascular invasion, and existence of metastasis, necrosis and Ki-67 expression can only be detected pathologically $(2,4)$. There are no tumor markers used routinely in predicting the prognosis of PNETs especially in the pre-operative period and in determining treatment strategy. Therefore, markers are needed for predicting malign behaviors and prognosis. The gold standard in determining the treatment for PNETs is the stage of the disease. Staging systems adopted by World Health Organization (WHO), American Joint Cancer Commission (AJCC) and European Neuroendocrine Tumor Society (ENETS) are used in staging the disease. While AJCC classification system was created on the basis of TNM system used for pancreatic adenocarcinoma, the ENETS system was created on the basis of studies involving PNET patients with large series. There are differences between the two systems of classification in terms of determining treatment and their effects on prognosis $(8,9)$. The differences are more remarkable especially in stage 1 and stage 3 diseases. Therefore, new markers are needed for guidance in arranging the treatment and for use in estimating prognosis. 
It is clearly known that cancer is closely related to local and systemic inflammatory response (10). Tumor-related inflammatory response mechanism contains several inflammatory mediators and cells. Besides playing roles in tumor progression and pathogenesis, inflammatory process can also cause changes in response to anti-tumoral treatment. Thus, inflammatory response causes changes in hematological parameters such as neutrophil, lymphocyte, monocyte and platelet. Changes, the increase in the amount of neutrophil and decrease in the number of lymphocytes for instance, are indicators of systemic inflammation. Therefore, neutrophil/lymphocyte ratio (NLR)- which is derived by dividing the number of neutrophils into the number of lymphocytes- and platelet/lymphocyte ratios (PLR)- which is derived by dividing the number of platelet into the number of lymphocytes- have attracted attention recently and become simple and useful prognostic markers in many types of cancer (11). In recent years, increased NLR and PLR values prior to treatment and deteriorated prognosis in colorectal, breast, gastric, liver and pancreatic cancers have been found to be associated with shortening of survival time and with deterioration in responding to treatment (12-15). It has been demonstrated by those studies that indicators of systemic inflammatory response play critical roles in cancer growth (10). Nevertheless, there is small number of studies that evaluated the prognostic role of NLR and PLR in PNETS.

With the hypothesis that NLR and PLR -the indicators of systemic inflammatory response- can vary with the stage of PNETs, this clinical study aimed to analyze the correlations between ENETS and TNM staging systems and pre-operative NLR and PLR levels.

\section{MATERIAL and METHODS}

\section{Patients}

Clinicopathologic data coming from 44 patients who had been histopathologically diagnosed to have PNET in our hospital in the period between March 2010 and April 2017 were analyzed retrospectively. Ethics committee approval was received for this study from the Ethics Committee of Gazi University (No. 2018/108). Informed consent form was obtained from all patients. The number of neutrophils, lymphocytes and platelets was determined from peripheral blood samples taken in the pre-operative period based on demographic data such as age and gender, and tumors were divided into categories as low, intermediate and high grade according to WHO 2010 (16). The patients were staged according to TNM staging systems adopted by ENETS and AJCC ( $7^{\text {th }}$ edition). The period between the date of operation and the date of death or of last monitoring was regarded as survival time. Patients with infection, hematologic diseases, renal dysfunctions and earlier cancer history were excluded from the study. The control group was composed of 44 healthy individuals who were consistent with the study group in age and gender and who had consulted our hospital for check-up.

\section{NLR and PLR Calculation}

Circulating blood count (CBC), which was routinely checked prior to operations for each patient, was recorded on the database of the study. CBC of the individuals in the control group during check-up was also recorded. NLR was calculated using the proportion of absolute neutrophil count in circulating blood to absolute lymphocyte count. In the same way, it was calculated by dividing PLR absolute platelet count into absolute lymphocyte count.

\section{Statistical Analysis}

All statistical analyses were done on IBM SPSS 20.0 (IBM Corp., Armonk, New-York, USA) version, and $\mathrm{p}<0.05$ values were considered statistically significant. Continuous data were analyzed using mean, median, standard deviation and 95\% confidence interval. Kolmogrov-Smirnov test was used in finding whether or not the data fit normal distribution. Independent $t$ test was used in comparing the variables consistent with normal distribution, whereas Mann-Whitney $U$ test was used in comparing the variables inconsistent with normal distribution. Eta correlation analysis (Ordinal by interval) was used for the relationship between NLR/PLR and both tumor stages.

\section{RESULTS}

\section{Patient Characteristics}

Demographic data concerning the patients are shown in Table 1. Median age of the patients was 54 (range: 24-73). Twenty-one of the patients were females while 23 of them were males. Median tumor diameter was $2.7 \mathrm{~cm}$ (range: 0.3-10). Patient distribution according to TNM and ENETS stages are presented in Table 1. Comparison of the patients with PNET according to ENETS and TNM classification systems are shown in Table 2. Pathologic evaluation revealed that 18 patients (40.9\%) had lymph node metastasis.

\section{Evaluation of Inflammatory Markers (NLR and PLR) in PNET Patients and Control Group}

As illustrated in Table 1, neutrophil and platelet counts were higher and lymphocyte counts were lower in PNET patients when compared with controls. Median NLR was 2.4 (range; 1.25.2) in PNET patients and in healthy controls, median NLR value was 1.8 (range; 0.9-3.7). Likewise, median PLR level was 122 (range: 71-245) in healthy controls and 127 (range: 59-500) in patients with PNET.

\section{Relationship of NLR and PLR Levels with ENETS Classification in PNET Patients}

The correlation between NLR and PLR levels with ENETS stage is shown in Table 3. It was suggested that there was a significant association between tumor stages with NLR, PLR and platelet levels $(p<0.05)$. While stage I had the lowest values, stage IV had the highest values. NLR, PLR and platelet levels had a tendency to increase following the tumor stages and were observed with a 
Table 1. Demographic, laboratory, and clinicopathologic features of patients with PNET and healthy control group

\begin{tabular}{|c|c|c|c|}
\hline & PNET patients & Control & $p$ \\
\hline Age, year & $53(24-70)$ & $51(30-88)$ & 0.869 \\
\hline Male/Female & $23 / 21$ & $23 / 21$ & 0.812 \\
\hline Neutrophil $\left(10^{9} / \mathrm{L}\right)$ & $4.3(2.3-9.3)$ & $3.8(1.7-6.2)$ & 0.042 \\
\hline Lymphocyte $\left(10^{9} / \mathrm{L}\right)$ & $1.5(0.9-3.3)$ & $2.0(1.0-2.7)$ & 0.038 \\
\hline Platelet $\left(10^{9} / \mathrm{L}\right)$ & $258(112-609)$ & $247(134-442)$ & 0.534 \\
\hline NLR & $2.4(1.2-5.2)$ & $1.8(0.9-3.7)$ & 0.001 \\
\hline PLR & $127(59-500)$ & $122(71-245)$ & 0.188 \\
\hline Tumor size, cm & $\begin{array}{c}2.9 \pm 2.6 \\
2.7(0.3-10)\end{array}$ & & \\
\hline $\begin{array}{l}\text { Lymph node metastasis } \\
\text { Positive } \\
\text { Negative }\end{array}$ & $\begin{array}{l}18(40.9) \\
26(59.0)\end{array}$ & & \\
\hline $\begin{array}{l}\text { WHO grade, } \mathrm{n}(\%) \\
\qquad \begin{array}{l}\text { G1 } \\
\text { G2 } \\
\text { G3 }\end{array}\end{array}$ & $\begin{array}{c}26(59.0) \\
3(6.8) \\
15(34.0)\end{array}$ & & \\
\hline $\begin{array}{c}\text { ENETS stage, n (\%) } \\
\text { Stage } 1 \\
\text { Stage } 2 \\
\text { Stage } 3 \\
\text { Stage } 4\end{array}$ & $\begin{array}{l}15(34.0) \\
11(25.0) \\
9(20.4) \\
9(20.4)\end{array}$ & & \\
\hline $\begin{array}{l}\text { AJCC TNM stage, n (\%) } \\
\text { Stage } 1 \\
\text { Stage } 2 \\
\text { Stage } 3 \\
\text { Stage } 4\end{array}$ & $\begin{array}{l}23(52.2) \\
9(20.4) \\
3(6.8) \\
9(20.4)\end{array}$ & & \\
\hline
\end{tabular}

Table 2. Comparison of patients with PNET according to ENETS and TNM classification systems

\begin{tabular}{|c|c|c|c|c|}
\hline & ENETS stage 1 & ENETS stage 2 & ENETS stage 3 & ENETS stage 4 \\
\hline TNM stage 1 & 15 & 8 & 0 & 0 \\
\hline TNM stage 2 & 0 & 3 & 6 & 0 \\
\hline TNM stage 3 & 0 & 0 & 3 & 0 \\
\hline TNM stage 4 & 0 & 0 & 0 & 9 \\
\hline
\end{tabular}

significantly demonstrable higher level as of stage IV. Neutrophil and lymphocyte levels did not significantly correlate with tumor stages, but a tendency to increase for the neutrophil count and a tendency to decrease for the lymphocyte were observed.

In contrast with the controls, rise in NLR started at stage I, and there was tendency to rise in parallel to the increase in stages. While the differences between Stage I patients' NLR and control group's NLR were not statistically significant, the differences be- tween Stage II, III and IV patients' NLR and control group's NLR were statistically significant. Besides, the differences between stage III and IV patients' NLR and stage II patients' NLR were also statistically significant (Table 3).

Yet, rise curve for PLR did not start at stage I. In addition to that, PLR at stage I decreased in comparison to the control group while it increased at stage $\|$ and reached the maximum value at stage IV. High values in Stage II patients' PLR were found to 
Table 3. The relation between lymphocyte, neutrophil, platelet, NLR and PLR according to ENETS staging system

\begin{tabular}{|l|c|c|c|c|c|c|}
\hline & Stage I & Stage II & Stage III & Stage IV & Control & p \\
\hline Lymphocyte & $2.0 \pm 0.7$ & $1.6 \pm 0.5$ & $1.4 \pm 0.3$ & $1.3 \pm 1.1^{\mathrm{a}, \mathrm{b}}$ & $2.0 \pm 0.4$ & 0.066 \\
\hline Neutrophil & $4.2 \pm 1.6$ & $4.3 \pm 0.8$ & $5.1 \pm 1.9$ & $5.5 \pm 1.7^{\mathrm{a}}$ & $3.8 \pm 1.1$ & 0.242 \\
\hline Platelet & $197 \pm 65$ & $276 \pm 44^{\mathrm{a}, \mathrm{b}}$ & $387 \pm 110^{\mathrm{a}, \mathrm{b}, \mathrm{c}}$ & $411 \pm 92^{\mathrm{a}, \mathrm{b}, \mathrm{c}}$ & $247 \pm 63$ & $\mathbf{0 . 0 0 0 1}$ \\
\hline NLR & $2.1 \pm 0.5$ & $2.8 \pm 0.7^{\mathrm{a}}$ & $3.4 \pm 1.2^{\mathrm{a}, \mathrm{b}}$ & $4.2 \pm 1.1^{\mathrm{a}, \mathrm{b}, \mathrm{c}}$ & $1.8 \pm 0.9$ & $\mathbf{0 . 0 0 0 1}$ \\
\hline PLR & $107 \pm 23$ & $179 \pm 51^{\mathrm{a}, \mathrm{b}}$ & $284 \pm 129^{\mathrm{a}, \mathrm{b}}$ & $324 \pm 105^{\mathrm{a}, \mathrm{b}, \mathrm{c}}$ & $122 \pm 71$ & $\mathbf{0 . 0 0 0 1}$ \\
\hline
\end{tabular}

NLR: Neutrophil/lymphocyte ratio, PLR: Platelet/lymphocyte ratio, ENETS: European Neuroendocrine Tumor Society.

Kruskal-Wallis test; when compared with control group ${ }^{a} p<0.05$, Compared with Stage $I^{b} p<0.05$, Compared with Stage $\|{ }^{c} p<0.05$. Bold values are statistically significant.

Table 4. The relation between lymphocyte, neutrophil, platelet, NLR and PLR according to TNM staging system

\begin{tabular}{|c|c|c|c|c|c|c|}
\hline & Stage I & Stage II & Stage III & Stage IV & Control & $p$ \\
\hline Lymphocyte & $1.9 \pm 0.6$ & $1.6 \pm 0.5$ & $1.2 \pm 0.1$ & $1.3 \pm 1.1^{b}$ & $2.0 \pm 0.4$ & 0.065 \\
\hline Neutrophil & $4.3 \pm 1.4$ & $4.5 \pm 1.7$ & $5.8 \pm 1.4$ & $5.5 \pm 1.7$ & $3.8 \pm 1.1$ & 0.163 \\
\hline Platelet & $221 \pm 66$ & $332 \pm 71^{a, b}$ & $468 \pm 131^{a, b}$ & $411 \pm 92^{a, b, c}$ & $247 \pm 63$ & 0.0001 \\
\hline NLR & $2.4 \pm 0.7$ & $2.7 \pm 0.8^{\mathrm{a}}$ & $4.6 \pm 0.8^{a, b, c}$ & $4.2 \pm 1.1^{a, b, c}$ & $1.8 \pm 0.9$ & 0.0001 \\
\hline PLR & $127 \pm 53$ & $194 \pm 115^{a, b}$ & $366 \pm 71^{a, b}$ & $324 \pm 105^{a, b, c}$ & $122 \pm 71$ & 0.0001 \\
\hline
\end{tabular}

be statistically significant in comparison with the control group and stage I group. Similarly, stage IV group- in which maximum PLR values were found- the highness in values was found statistically significant upon comparing it with the values for the control group and the Stage I and Stage II groups (Table 3).

Upon comparing the control group with stage II, III and IV groups in terms of the number of platelets; the differences between stages in the number of lymphocytes and neutrophils were not found significant (Table 3).

There was a strong positive correlation between NLR/PLR and ENETS staging system $(r=0.58$ and $p=0.0001, r=0.76$ and $p=$ 0.0001 , respectively), which means that NLR levels increase as the ENET stages progress.

\section{Relationship of NLR and PLR Levels with TNM Stages in PNET Patients}

The relationship between NLR, PLR and other parameters with TNM stage are presented in Table 4. It was suggested that there was a significant relationship between tumor stages (I to IV) with NLR, PLR and platelet levels $(p<0.05)$. While stage I had the lowest values, stage IV had the highest values. NLR, PLR and platelet levels had a tendency to increase following the tumor stages and were observed with a significantly detectable higher level as of stage IV. Neutrophil and lymphocyte levels did not significantly correlate with tumor stages, but a tendency to increase for the neutrophil count and a tendency to decrease for the lymphocyte was observed.
In contrast with the control group, rise in NLR started at stage I and tended to increase. While the differences between stage I patients' NLR and control group's NLR were statistically insignificant, the differences between Stage II, III and IV patients' NLR and control group's NLR were significant. Besides, while the differences between stage IV patients' NLR and stage I and II patients' NLR were statistically significant, the differences between stage III patients' NLR were statistically insignificant (Table 4).

In a similar way, rise curve for PLR started at stage I and it reached the maximum value at stage IV. Highness in stage II, II and IV patients'PLR was found to be statistically significant when compared to control group's values. Upon comparing stage II and stage III patients' PLR values, stage III patients' PLR was found to be higher than those of stage II but the high values were not found statistically significant (Table 4). There was a strong positive correlation between NLR/PLR and TNM staging system ( $r=$ 0.59 and $p=0.0001, r=0.74$ and $p=0.0001$, respectively), which means that NLR levels increase as the TNM stages progress.

Upon comparing the control group with all stage groups in terms of the number of platelets, it was found that the difference between stage IV group and the control group was significant and that the changes in the other groups were also significant. Apart from that, the differences between stages in terms of lymphocyte and neutrophil counts were not statistically significant either (Table 4). 


\section{DISCUSSION}

Neuroendocrine tumors are a type of cancer associated with inflammation (17). This study, which was conducted with inflammatory markers such as NLR and PLR displaying the inflammatory and immunity situation comprehensively in cancer patients, demonstrated that PNET was a reliable indicator in predicting survival of patients having different types of tumors such as pancreatic adenocarcinoma, colorectal cancer, hepatocellular cancer carcinoma, gastric neuroendocrine tumors and breast cancer $(11,13-15,18)$. It was thought based on these studies that inflammatory markers such as NLR and PLR could be useful in prognosis of PNET patients and of their response to treatment, and this current study analyzed the correlations between NLR, PLR and tumors and TNM and ENETS staging systems separately in patients diagnosed to have PNET. The reason for this is that single staging method is not used in the world today for PNET patients. While ENETS system is frequently used in Europe, AJCC system is often used in the USA (6). For this reason, there is controversy in determining the prognosis for PNET patients and in the selection of treatment protocols. Lou et al. have demonstrated that stage 3 disease rates were rare in AJCC system, that the prognosis of stage 1 and stage 2 patients was similar in ENETS system and that stage 3A patients' prognosis was worse than the prognosis of stage 3B patients (16). Therefore, it is argued that staging systems should be modified.

It was observed in this study that NLR and PLR levels were significantly lower in healthy controls than PNET patients. Moreover, it was seen that NLR and PLR had a tendency to increase at each stage of the disease. Based on these results, it could be claimed that neutrophil and platelet dependent inflammation processes may play active roles at different stages of PNET.

Tong et al. have shown that NLR and PLR levels were higher in metastatic but resectable tumors with PNET patients (advanced stage) (19). These findings are consistent with our study. Increasing levels or both markers are reflective of the active interaction between in vivo tumor loads and host immune system. In addition to demonstrating the importance of NLR and PLR in PNET diagnosis, this study also showed the changes of both markers depending on tumor stages. This study put forth that both NLR and PLR had risen at earlier stages of the tumor. Thus, it is suggested that neutrophil and platelet provided early reaction in PNET's development, which causes the increase in NLR and PLR levels. In addition to the fact that both markers can provide important information in the pre-operative period in early diagnosis of PNET patients, the fact that this situation is not specific to PNET patients is a disadvantage considering that these markers can rise in any inflammation of metabolism.

Salman $T$ et al. have reported that high levels of NLR and PLR are associated with high grade and advanced stage (20). In their prospective study conducted with 97 patients diagnosed to have PNET, Giatanidis et al. have demonstrated that NLR is an independent predictive determiner of survival in PNET patients (21). Besides, preoperative NLR is a potentially independent predictor for disease progression and lower lymphocyte-to-monocyte ratios is an independent predictor or tumor recurrence with PNETS.

In many studies, it has been demonstrated that inflammatory markers such as neutrophils and platelets are played a critically role in tumor development and metastasis (22-24). Higher NLR and PLR is possible with the elevation in neutrophil and thrombocyte counts and with the decrease in lymphocyte counts, which in turn gives mediated anti-tumor immune response with increased neutrophil and increased platelet dependent inflammatory reactions. We believe that NLR and PLR can reflect inflammation cascade results playing roles in the development of cancer in PNET patients. Neutrophils, which are among immunity cells, are rapidly activated and when they encounter inflammatory signals, they migrate to the inflamed region. Continual stimulus to neutrophils depending on chronic inflammation causes severe oxidative stress leading to promutagenic DNA damage (24). The tumor formed causes the release of bio-substances such as interleucin- 6 and tissue factor encouraging thrombocyte production and more circulation of activated thrombocytes in circulation (25-27). On the other hand, activated thrombocyte sets granule components such as vascular endothelial growth factor, platelet derived growth factor and transformatory growth factor- $\beta$ free, and thus, they contribute to tumor growth (22). Inflammatory cells, which also include leukocytes and lymphocytes, play important roles in controlling the proliferation, survival and migration of tumor cells through apoptosis and angiogenesis (28-30).

Zhang et al. have demonstrated that the abundance of tumor-related neutrophils in circulation in patients with advanced cancer inhibited the activation of peripheral leucocytes and contributed to tumor metastasis (31). Other studies showed that tumor-related neutrophils supported tumor proliferation, that they set free pro-angiogenic mediators (VEGF), facilitated metastasis and that they caused more aggressive tumors (32). It has been described in an experimental breast cancer model that the main component and control of metastatic formation in lung tissue was arranged by neutrophil (33). Besides, if neutrophils are activated adequately in endothelial cells, they can support the sticking of tumor cells to a lymphatic endothelial cell $(34,35)$. Both markers in this study changed differently at earlier stages of PNET and they had similarities displaying significant changes at stages II and III. The underlying mechanism is indefinite at present. Nonetheless, NLR and PLR levels had the highest increase at stage III and showed the important role inflammatory response played in the progress of PNET. We observed that myeloid cells created the inflammatory micro 
framework necessary for EMT, intravasation and metastasis and they facilitated tumor developments' transition into the other stages. In a study conducted with mouse models, it has been reported that neutrophil-mediated immune response played critical roles in spontaneous breast cancer metastasis (36). The difference between both indices in terms of tumor stage responses should reflect the different pathophysiological roles inflammation in tumor growth. It has been reported that NLR was a superior prognostic and predictive marker in PNETs when compared to PLR (37). In addition to the above-mentioned findings, this current study shows that PLR and NLR are directly related to tumor invasion (T stage) in PNET and prevalence of lymph node metastasis. These observations can be associated with the role thrombocytes, in thrombocyte-cancer interaction cycle, play in favor of releasing thrombocyte granule content and of cancer growth (22). In a similar way, it has been found that malign over cancer cells and thrombocytes which were activated in the process of tumor development had increased tumor cell invasion depending on dose (38). In a recent study, it has been suggested that thrombocytes stimulated colon cancer development. It has been found that thrombocyte derived trombospondin 1 and klusterin increased the gene expression of MMP-9 by means of P38MAPK route (39).

Although the biology underlying the above mentioned changes in NLR and PLR is indefinite, it is widely accepted that tumor development is associated with inflammation and immunity. Inflammatory mediators and cytokines such as epidermal growth factor, transformatory growth factor-beta (TGF-beta), tumor necrosis factor-alpha (TNF-alpha), fibroblast growth factors (FGFs) and interleukins (IL-4, IL-8, IL-10 and IL-13) stimulate angiogenesis as a part of tumor or natural host immune response, cause matrix degradation and cancer progression, and thus, facilitate immunosuppression $(29,40)$. Transcription factors such as NF-kappa B and STAT2 are activated by means of pathophysiological paths, and this causes inflammatory mediators and leukocytes to be suppressed around the tumor (41). Microenvironment, which is together with this inflammatory process, increases tumor development and accelerates the process of metastasis.

This study demonstrated that NLR and PLR values can be included in AJCC $(r=0.59$ and $p=0.0001, r=0.74$ and $p=0.0001$, respectively) and ENETS staging ( $r=0.58$ and $p=0.0001, r=0.76$ and $p=0.0001$, respectively) systems and that there are strong correlations with the stages of the disease in PNET patients, which means that NLR levels increase as the TNM and ENETS tumor stages progress. This study analyzed the perspectives of correlations between the changes in preoperative NLR and PLR levels and tumor stages. This can also help in the selection of treatment for PNET patients or in evaluating responses to the treatment. Besides, we also believe that the study can inform us whether or not using medicine, which is a derivation of an- tithrombotic factor, would be useful as PLR levels rise and the stages progress in PNET patients. Another clinic importance of this study is that it can help explain some cancer behaviors, detect PNET patients earlier and find potential markers in order to be able to determine the response to treatment.

On the other hand, this study had certain limitations. Firstly, the study was designed as a retrospective study. Secondly, since NLR and PLR, which were the signs of systemic inflammation, were influenced by several factors such as chronic and acute inflammatory diseases, they reduced the sensitivity of our results. Therefore, these conditions should be verified by studies with prospective and high patient numbers.

\section{CONCLUSION}

In conclusion, this study demonstrated that increased level of inflammatory mediators such as NLR and PLR were associated with advanced stages of tumor in PNET patients. Neutrophils and thrombocytes may play important roles in cancer prognosis at different stages. Both parameters showed that there could be simple, potential markers usable in pre-operative period in determining the tumor stages in PNET patients. Prospective studies with the inclusion of bigger number of patients are urgently needed.

Ethics Committee Approval: Ethics committee approval was received for this study from the Ethics Committee of Gazi University (No. 2018/108).

Informed Consent: Informed consent form was obtained from all patients. Peer-review: Externally peer-reviewed.

Author Contributions: Concept - K.D., M.K.; Design - K.D., M.K.; Supervision - M.K.; Resource - K.D., M.K.; Materials - K.D., M.K.; Data Collection and/or Processing - K.D., M.K.; Analysis and Interpretation - K.D., M.K.; Literature Review - K.D., M.K.; Writing Manuscript - K.D.; Critical Reviews - K.D., M.K.

Conflict of Interest: The authors have no conflicts of interest.

Financial Disclosure: The authors declared that this study has received no financial support.

\section{REFERENCES}

1. Cortez E, Gladh H, Braun S, Bocci M, Cordero E, Bjorkstrom NK, et al. Functional malignant cell heterogeneity in pancreatic neuroendocrine tumors revealed by targeting of PDGF-DD. Proc Natl Acad Sci U S A 2016;113(7):E864-73. [CrossRef]

2. Frilling A, Modlin IM, Kidd M, Russell C, Breitenstein S, Salem R, et al. Recommendations for management of patients with neuroendocrine liver metastases. Lancet Oncol 2014;15(1):e8-21. [CrossRef]

3. Panzuto F, Boninsegna L, Fazio N, Campana D, Pia Brizzi M, Capurso $G$, et al. Metastatic and locally advanced pancreatic endocrine carcinomas: analysis of factors associated with disease progression. J Clin Oncol 2011;29(17):2372-7. [CrossRef]

4. Yao JC, Hassan M, Phan A, Dagohoy C, Leary C, Mares JE, et al. One hundred years after "carcinoid": epidemiology of and prognostic factors for neuroendocrine tumors in 35,825 cases in the United States. J Clin Oncol 2008;26(18):3063-72. [CrossRef] 
5. Fischer L, Kleeff J, Esposito I, Hinz U, Zimmermann A, Friess H, et al. Clinical outcome and long-term survival in 118 consecutive patients with neuroendocrine tumours of the pancreas. Br J Surg 2008;95(5):627-35. [CrossRef]

6. Kloppel G, Rindi G, Perren A, Komminoth P, Klimstra DS. The ENETS and AJCC/UICC TNM classifications of the neuroendocrine tumors of the gastrointestinal tract and the pancreas: a statement. Virchows Arch 2010;456(6):595-7. [CrossRef]

7. Rindi G, Falconi M, Klersy C, Albarello L, Boninsegna L, Buchler MW, et al. TNM staging of neoplasms of the endocrine pancreas: results from a large international cohortstudy. J Natl Cancer Inst 2012;104(10):76477. [CrossRef]

8. Ellison TA, Wolfgang CL, Shi C, Cameron JL, Murakami P, Mun L, et al. A single institution's 26-year experience with nonfunctional pancreatic neuroendocrine tumors: a validation of current staging systems and a new prognostic nomogram. Ann Surg 2014;259(2):204-12. [CrossRef]

9. Strosberg JR, Cheema A, Weber J, Han G, Coppola D, Kvols LK. Prognostic validity of a novel American Joint Committee on Cancer Staging Classification for pancreatic neuroendocrine tumors. J Clin Oncol 2011;29(22):3044-9. [CrossRef]

10. Jia J, Zheng X, Chen Y, Wang L, Lin L, YeX, et al. Stage-dependent changes of preoperative neutrophil to lymphocyte ratio and platelet to lymphocyte ratio in colorectal cancer. Tumour Biol 2015;36(12):931925. [CrossRef]

11. Zhou B, Zhan C, Wu J, Liu J, Zhou J, Zheng S. Prognostic significance of preoperative neutrophil-to-lymphocyte ratio in surgically resectable pancreatic neuroendocrine tumors. Med Sci Monit 2017;23:5574-88. [CrossRef]

12. Azab B, Bhatt VR, Phookan J, Murukutla S, Kohn N, Terjanian T, et al. Usefulness of the neutrophil-to-lymphocyte ratio in predicting shortand long-term mortality in breast cancer patients. Ann Surg Oncol 2012;19(1):217-24. [CrossRef]

13. Cao LL, Lu J, Lin JX, Zheng CH, Li P, Xie JW, et al. A novel predictive model based on preoperative blood neutrophil-to-lymphocyte ratio for survival prognosis in patients with gastric neuroendocrine neoplasms. Oncotarget 2016;7(27):42045-58. [CrossRef]

14. Mano Y, Shirabe K, Yamashita Y, Harimoto N, Tsujita E, Takeishi K, et al. Preoperative neutrophil-to-lymphocyte ratio is a predictor of survival after hepatectomy for hepatocellular carcinoma: a retrospective analysis. Ann Surg 2013;258(2):301-5. [CrossRef]

15. Paramanathan A, Saxena A, Morris DL. A systematic review and meta-analysis on the impact of pre-operative neutrophil lymphocyte ratio on long term outcomes after curative intent resection of solid tumours. Surg Oncol 2014;23(1):31-9. [CrossRef]

16. Luo G, Javed A, Strosberg JR, Jin K, Zhang Y, Liu C, et al. Modified staging classification for pancreatic neuroendocrine tumors on the basis of the American Joint Committee on Cancer and European Neuroendocrine Tumor Society Systems. J Clin Oncol 2017;35(3):274-80. [CrossRef]

17. Kasajima A, Ishikawa Y, Iwata A, Steiger K, Oka N, Ishida H, et al. Inflammation and PD-L1 expression in pulmonary neuroendocrine tumors. Endocr Relat Cancer 2018;25(3):339-50. [CrossRef]

18. Kwon HC, Kim SH, Oh SY, Lee S, Lee JH, Choi HJ, et al. Clinical significance of preoperative neutrophil-lymphocyte versus plateletlymphocyte ratio in patients with operable colorectal cancer. Biomarkers 2012;17(3):216-22. [CrossRef]

19. Tong Z, Liu L, Zheng Y, Jiang W, Zhao P, Fang W, et al. Predictive value of preoperative peripheral blood neutrophil/lymphocyte ratio for lymph node metastasis in patients of resectable pancreatic neuroendocrine tumors: a nomogram-based study. World J Surg Oncol 2017;15(1):108. [CrossRef]
20. Salman T, Kazaz SN, Varol U, Oflazoglu U, Unek IT, Kucukzeybek Y, et al. Prognostic value of the pretreatment neutrophil-to-lymphocyte ratio and platelet-to-lymphocyte ratio for patients with neuroendocrine tumors: an Izmir Oncology Group Study. Chemother 2016;61 (6):281-6. [CrossRef]

21. Gaitanidis A, Patel D, Nilubol N, Tirosh A, Sadowski S, Kebebew E. Markers of systemic inflammatory response are prognostic factors in patients with pancreatic neuroendocrine tumors (PNETS): a prospective analysis. Ann Surg Oncol 2018;25(1):122-30. [CrossRef]

22. Goubran HA, Burnouf T, Radosevic M, El-Ekiaby M. The platelet-cancer loop. Eur J Intern Med 2013;24(5):393-400. [CrossRef]

23. Grivennikov SI. Inflammation and colorectal cancer: colitis-associated neoplasia. Semin Immunopathol 2013;35(2):229-44. [CrossRef]

24. Mariani F, Sena P, Roncucci L. Inflammatory pathways in the early steps of colorectal cancer development. World I Gastroenterol 2014;20(29):9716-31. [CrossRef]

25. Goubran HA, Stakiw J, Radosevic M, Burnouf T. Platelet-cancer interactions. Semin Thromb Hemost 2014;40(3):296-305. [CrossRef]

26. Kaser A, Brandacher G, Steurer W, Kaser S, Offner FA, Zoller H, et al. Interleukin-6 stimulates thrombopoiesis through thrombopoietin: role in inflammatory thrombocytosis. Blood 2001;98(9):2720-5. [CrossRef]

27. van Rossum AP, Vlasveld LT, Vlasveld IN, Jansen PM, Dik WA, Hooijkaas $H$, et al. Granulocytosis and thrombocytosis in renal cell carcinoma: a pro-inflammatory cytokine response originating in the tumour. Neth J Med 2009;67(5):191-4. [CrossRef]

28. Coussens LM, Werb Z. Inflammation and cancer. Nature 2002;420(6917):860-7. [CrossRef]

29. Lippitz BE. Cytokine patterns in patients with cancer: a systematic review. Lancet Oncol 2013;14(6):e218-28. [CrossRef]

30. Popivanova BK, Kitamura K, Wu Y, Kondo T, Kagaya T, Kaneko S, et al. Blocking TNF-alpha in mice reduces colorectal carcinogenesis associated with chronic colitis. J Clin Invest 2008; 118(2):560-70. [CrossRef]

31. Zhang J, Qiao X, Shi H, Han X, Liu W, Tian X, et al. Circulating tumorassociated neutrophils (CTAN) contribute to circulating tumor cell survival by suppressing peripheral leukocyte activation. Tumour Biol 2016;37(4):5397-404. [CrossRef]

32. Spolverato G, Maqsood H, Kim Y, Margonis G, Luo T, Ejaz A, et al. Neutrophil-lymphocyte and platelet-lymphocyte ratio in patients after resection for hepato-pancreatico-biliary malignancies. J Surg Oncol 2015;111(7):868-74. [CrossRef]

33. Wculek SK, Malanchi I. Neutrophils support lung colonization of metastasis-initiating breast cancer cells. Nature 2015;528(7582):413-7. [CrossRef]

34. Fu C, Tong C, Wang M, Gao Y, Zhang Y, Lu S, et al. Determining beta2integrin and intercellular adhesion molecule 1 binding kinetics in tumor cell adhesion to leukocytes and endothelial cells by a gas-driven micropipette assay. J Biol Chem 2011;286(40):34777-87. [CrossRef]

35. Lee YS, Choi I, Ning Y, Kim NY, Khatchadourian V, Yang D, et al. Interleukin-8 and its receptor CXCR2 in the tumour microenvironment promote colon cancer growth, progression and metastasis. Br J Cancer 2012;106(11):1833-41. [CrossRef]

36. Coffelt SB, Kersten K, Doornebal CW, Weiden J, Vrijland K, Hau CS, et al. IL17-producing gammadelta $T$ cells and neutrophils conspire to promote breast cancer metastasis. Nature 2015;522(7556):345-8. [CrossRef]

37. He W, Yin C, Guo G, Jiang C, Wang F, Qiu H, et al. Initial neutrophil lymphocyte ratio is superior to platelet lymphocyte ratio as an adverse prognostic and predictive factor in metastatic colorectal cancer. Med Oncol 2013;30(1):439. [CrossRef] 
38. Holmes CE, Levis JE, Ornstein DL. Activated platelets enhance ovarian cancer cell invasion in a cellular model of metastasis. Clin Exp Metas tasis 2009;26(7):653-61. [CrossRef]

39. Radziwon-Balicka A, Santos-Martinez MJ, Corbalan JJ, O'Sullivan S, Treumann A, Gilmer JF, et al. Mechanisms of platelet-stimulated colon cancer invasion: role of clusterin and thrombospondin 1 in regulation of the P38MAPK-MMP-9 pathway. Carcinogenesis 2014;35(2):324-32. [CrossRef]
40. Martinez A, Miller MJ, Unsworth EJ, Siegfried JM, Cuttitta F. Expression of adrenomedullin in normal human lung and in pulmonary tumors. Endocrinology 1995;136(9):4099-105. [CrossRef]

41. Grivennikov SI, Karin M. Dangerous liaisons: STAT3 and NF-kappaB collaboration and crosstalk in cancer. Cytokine Growth Factor Rev 2010;21(1):11-9. [CrossRef]

\title{
ORIJINAL ÇALIŞMA-ÖZET
}

Turk J Surg 2020; $36(1): 1-8$

\section{Pankreatik nöroendokrin tümörlerde nötrofil/lenfosit ve platelet/lenfosit oranlarına göre evre tahmini}

\author{
Kürşat Dikmen ${ }^{1}$, Mustafa Kerem ${ }^{1}$ \\ ${ }^{1}$ Gazi Üniversitesi Tıp Fakültesi, Genel Cerrahi Anabilim Dalı, Ankara, Türkiye
}

\section{ÖZET}

Giriş ve Amaç: Bu çalışmanın amacı, pankreas nöroendokrin tümör (PNET) tanılı hastalarda "European Neuroendocrine Tumor Society (ENEST)" ve "Tumor Node Metastasis (TNM)" evreleme sistemlerinin preoperatif nötrofil/lenfosit oranı (NLO) ve platelet/lenfosit oranı (PLO) ile ilişkisini analiz etmektir.

Gereç ve Yöntem: Mart 2010-Nisan 2017 tarihleri arasında histopatolojik alarak tanısı PNET olan 44 hastaya ait veriler retrospektif olarak incelendi. Hastaların preoperatif kan ve klinikopatolojik parametreleri değerlendirildi. Laboratuvar parametreleri ile tümör evreleri arasındaki ilişki Eta korelasyon analizi kullanılarak tespit edildi. Yaş ve cinsiyet bakımından çalışma grubumuzla benzer özellikte olan sağılılı gönüllüler çalışmamızın kontrol grubu olarak belirlendi.

Bulgular: ENETS sınıflamasına göre hastalar \%34 ( $n=15)$ evre 1, \%25 $(n=11)$ evre 2, \%20,4 $(n=9)$ evre 3 ve $\% 20,4(n=9)$ evre 4 idi. TNM evrelemesine göre hastalar $\% 52,2(n=23)$ evre $1, \% 20,4(n=9)$ evre $2, \% 6,8(n=3)$ evre 3 ve $\% 20,4(n=9)$ evre 4 idi. Çalışma grubunda NLO ve PLO değerleri ortancaları sırasıyla 2,4 (range: 1,2-5,2) ve 127 (range: 59-500) idi. Çalışma grubundaki hastaların NLO değerleri kontrol grubuna göre yüksekti ( $p=$ $0,001)$. ENETS sistemine göre Evre 1, 2, 3 ve 4 hastaların NLO ve PLO değerleri evre ilerledikçe yükselme eğilimindeydi (sırasıyla $p=0,0001$ ve $p=$ 0,0001). Benzer şekilde TNM sistemine göre de NLO ve PLO değerleri evre ilerledikçe artmaktaydı (sırasıyla $p=0,0001$ ve $p=0,0001$ ). Ayrıca lenf nodu metastazı olan hastalarda NLO değerleri olmayanlara göre daha yüksek bulunmuştur ( $p=0,001)$.

Sonuç: NLO ve PLO gibi enflamatuvar belirteçlerin yüksek olması PNET'li hastalarda ilerlemiş hastalık ile birliktelik göstermektedir.

Anahtar Kelimeler: Pankreas, nöroendokrin tümör, enflamasyon, evre

DOI: 10.5578/turkjsurg.4375 